\title{
CHANGES IN FOLKTALE SOCIALIZATION IN AN URBAN FULBE COMMUNITY
}

\author{
Leslie C. Moore
}

Thirty years ago, linguist, folklorist, and missionary Dominique Noye (1971) argued that the oral traditions of the Fulbe of Maroua, Cameroon-folktales, riddles, and tongue twisters - were a significant force for the maintenance of their conservative dialect of Fulfulde (known variously throughout West Africa as Fulani, Fula, Peul, Pulaar, etc.). He also predicted their imminent demise under the pressure of schooling, mass media, and urbanization. I found that the folktale tradition endures but that folktale socialization patterns are changing.

Traditionally, a Fulbe child learned folktales (taali) by observing performances by experts, typically older women of the family. A child would observe multiple tellings of the same tale during her childhood before ever attempting her own telling in public. By public, I mean an informal nighttime gathering (hiirde) of women and children in a family compound. In the past decade or so, a new way of teaching and learning folktales has become increasingly common in Maroua. This new socialization routine closely resembles those that dominate public and Koranic school interactions, a pattern I call Guided Repetition (Moore 2004).

Guided Repetition is a social practice for teaching and learning new skills that involve (i) modeling by an expert, (ii) imitation of that model by a novice, followed by (iii) rehearsal and (iv) performance by the novice. In each of these four phases, the expert supervises the novice and may assist, evaluate, and correct her efforts. The goal is that the novice masters the new skill.

In most instances in Koranic and public schooling, Modeling and Imitation are so intertwined on a turn-by-turn basis as to constitute one phase, as can be seen in transcripts 1 and 2 . Video recordings were transcribed using the following conventions: 


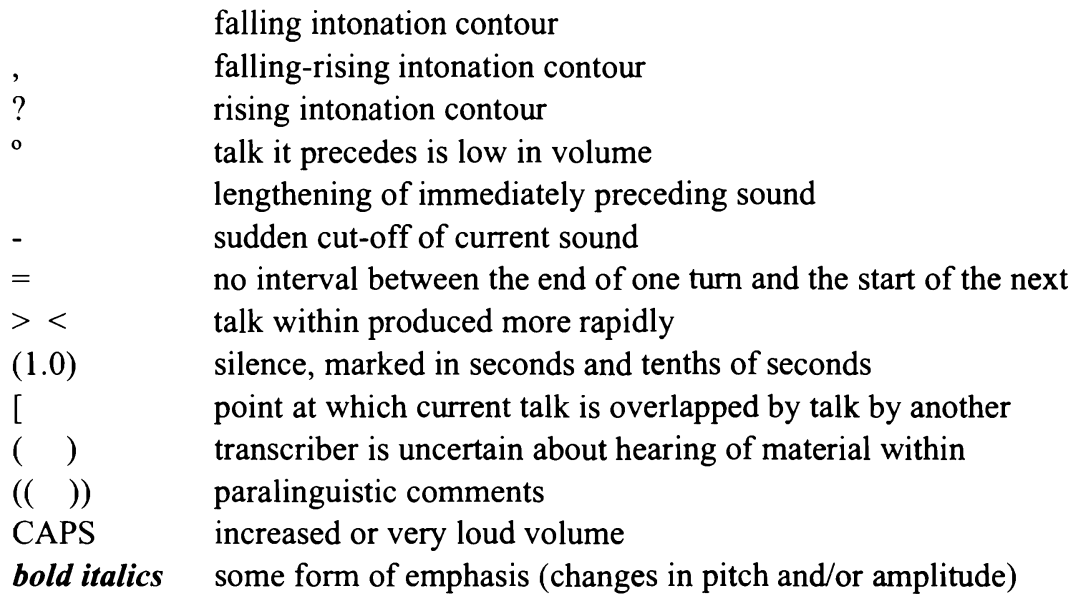

Transcript 1: Modeling and imitation in Koranic school $(T=$ Teacher, $S=$ Student $)$

1 T: Alheekum takasuru ((following with pen))

2 S: Alheekum takafuru

3 T: Alheekum takasuru ((following with pen))

4 S: Alheekum taka(s/f)uru

5 T: Hatta zurtu min ma qa'bira ((following with pen))

6 S: Hatta zurtu min ma ka'bira

7 T: Kalla sawfa tala muuna ((following with pen))

8 S: Kalla sawfa tala muuna

Transcript 2: Modeling and Imitation in public school $(T=$ Teacher, $C=$ Class $)$

1 T: BONJOUR PAPA. REPETEZ?

2 C: BONJOUR PAPA.

3 T: BONJOUR PAPA.

4 C: BONJOUR PAPA.

5 T: BONJOUR MON FILS.

$6 \quad(($ Silence, 1.0$))$ 


\section{T: ALLEZ-Y? \\ 8 C: BONJOUR MON FILS \\ 9 T: Très bien. ENCORE?}

Guided Repetition is emerging as a new practice for socializing children into the telling of folktales. In addition to telling folktales to an audience of children and women, expert tellers are explicitly teaching folktales to children. For their part, children, are assuming more vocal, active roles in the learning and telling of folktales at a much earlier age than in traditional folktale socialization. The same asymmetric, alternating interactional structure that is characteristic of Koranic and French language socialization has diffused into the home setting, as Transcript 3 illustrates. The expert models the folktale segment by segment, and the novice reproduces each segment after the expert, subject to assessment and correction by the expert. Here, Goggo Indu (GI) proposes to Muniira (M) that Goggo Indu will model a folktale (line 1) and Muniira will "follow" (tokkaago) (line 2), i.e., repeat after her. Muniira agrees, and Goggo Indu launches the tale of The Little Gazelle (line 4). When Muniira's cousin Ladiifa (L) joins in, Goggo Indu questions her vocal participation.

Transcript 3: Modeling-Imitation of a Folktale

$1 \quad$ GI: $\quad$ Haa mi taala kadi

I'll tell a folktale then

$2 \quad$ Tokko da an boo

As for you, you follow

3 M: Iyo,

Okay

4 GI: Lele ngel [he6i] nyebbe laamdo.

This little gazelle found the beans of the chief

5 M:

6

[Iyo:]

[nm::.:.]

Okay 
$7 \quad$ L: $\quad$ [A'a?]

$8 \quad$ GI: Nbii-da an boo?

You, you say it too?

9 M: $\quad$ Iyo. Lele [ngel]

Okay. This gazelle

10 L: [Lele] ngel

This gazelle

11 GI: A munya le,

You wait

$12 \mathrm{M}: \quad$ I- Lele ngel

O- This little gazelle

13 GI: He6i nyebbe laamdo.

Found the beans of the chief

14 M Lee6i (yebbe) laamdo.

Butters ( ) of the chief

15 All: ((laughter))

16 GI: Kadi boo a anndaa koo wolwugo.

Again you don't even know how to speak

17 An ekkitinii na,

You, teach

18 F: ((slowly)) He6ti nyebbe laamdo.

Found again the beans of the chief

19 GA: Nyebbe boo a anndaa na?

Even beans, you don't know?

20 GI: He6i nyebbe laamdo

found the beans of the chief 
21 M \& L: He6ti nyebbe laamdo found the beans of the chief

22 GI: don 'yakka, don 'yakka, was munching, was munching

23 M \& L: don 'yakka, don 'yakka, was munching, was munching

In lines 7-10, there is some confusion as to who is repeating after Goggo Indu: Muniira, Ladiifa, or both. Goggo Indu tells Ladiifa to wait (line 11), which the girl does, but then she joins in again 10 lines later (line 21). In Koranic school, Modeling-Imitation is a focused one-on-one encounter between expert and novice, while in public school this phase is usually accomplished chorally. Like all the other expert adult folktale tellers in my study, Goggo Indu had attended Koranic school but not public school. And like the other experts, she preferred to lead (tokkingo) only one child at a time through a folktale. The children, on the other hand, often engaged in these interactions chorally, both with experts and amongst themselves.

Muniira then reproduces (for the second time) the first part of the first segment modeled by Goggo Indu (line 12). Goggo Indu re-models the second part (line 13), and Muniira makes an unsuccessful attempt to repeat after her (line 14). There is general laughter, and Goggo Indu teases Muniira (line 16), chiding her for her lack of competence in speaking. Goggo Indu then invites Muniira's teenage sister Fadi to take over teaching the folktale (line 17). Enunciating carefully, Fadi models the second part, changing the verb slightly from hebi ('found') to the now more frequently used hebti ('found again') (line 18). The girls' visiting great-aunt asks Muniira if she does not know beans (line 19), and Goggo Indu resumes the role of teacher, re-modeling the second part of the first segment (line 20). Muniira and Ladiifa both repeat after her (reproducing, however, the verb form modeled by Fadi).

In this excerpt, Muniira's failure to reproduce Goggo Indu's model accurately was publicly constructed by her aunt and great-aunt as a lack of linguistic and sociocultural competence. Her lack of competence is, however, accommodated by her aunt and her sister. In the new form of folktale socialization, experts simplified the task of learning for the child by breaking down the folktale into short segments for the child to repeat. When a child had trouble reproducing the model, experts repeated the segment, often enunciating it more slowly and 
clearly, and/or breaking it down into even smaller segments. In some families, experts further simplified the task by using less complex vocabulary and morphosyntax in these teaching/learning routines than they did when performing a folktale.

Earlier in the session, Goggo Indu elicited from Muniira performance of a folktale that they had "told together" (Modeling-Imitation) on a previous evening.

Transcript 4: Performance of a Folktale

1 GI: Taala le kadi, jey taalu-noo-den-ngol

Tell a tale then, the one we told

2 L: Jey jiire

The one about squirrel

3 M: Taalel taalel

Little tale little tale

4

gombel gombel

little millet stalk little millet stalk

5

tuggere ngel

little millet stalk stump

6

Jiire oo (.) be don dilla

This squirrel, they were leaving for

7

hiirde

the evening get-together

8

Sui kadi mm mm

And then $\mathrm{mm} \mathrm{mm}$

9

o yecci o yecci o yecci

he told he told he told

10 o yecci [o yecci-

he told he told

11 GI: $\quad$ [O wi' yoo, nbi'at-a [o yecci yoo

He said, you said he told that

12 M: [O wi' yoo o wi' yoo

He said that he said that

13 ndill-en hiirde

let's go to the evening get-together 
$O$ yecci toy ke66et-en

He told where do we find

15 haa toy ke66et-en gaaraaji?

where at do we find thread?

16 O yecci haa Maruwa do don

He told right here in Maroua

17 GI: Haa Maruwa nii?

In Maroua like that?

18 D: ((laughs))

19 GI: A'a:: [Naa haa Maruwa

No. Not in Maroua

20 D: [Taal Ladiifa

Tell a tale Ladiifa

21 GI: be kiiroy (.)

They who passed the evening

22 be tawi maayo waddi

they found the river swollen

Muniira performs the opening formula (lines 3-5) and the setting of the scene (line 6) without difficulty. She has trouble, however, with reporting speech (line 9), repeating the same phrase five times (lines 9 and 10). Goggo Indu interrupts to correct Muniira, modeling the correct verb of saying (wi'go) and telling her what she said that was incorrect (line 11). I have translated o yecci as 'he told', but I might have translated it as 'he was like', for this use of the verb yeccugo ('to tell') is common among Maroua Fulbe children (and non-native speakers of Fulfulde) and abhorred by many adult Fulbe. Muniira twice repeats the phrase modeled by Goggo Indu (line 12) and resumes her telling. One line later, however, she uses yeccugo again to introduce reported speech (line 14), and again in line 16.

Goggo Indu does not correct the linguistic error. Rather, she responds to Muniira's violation of a convention of the genre. One characteristic that distinguishes folktales (taali) from other narrative genres among the Fulbe is that they take place in an imaginary domain. Gecci (accounts, legends, traditions of the Prophet), in contrast, are about events that actually took place, involving real places and people (Baumgardt \& Addi 2000). Muniira blends the two genres by 
naming Maroua in her telling of the folktale (line 16), and Goggo Indu questions and corrects her on this point (lines 17 and 19).

Several adults complained of children's penchant for "mixing" (jiilgo) folktales. There were three types of mixing that Fulbe adults found objectionable: (i) the merging of two or more folktales, (ii) the insertion of modern elements into folktales (e.g., cars, policemen, restaurants), and (iii) the fusing of folktales with real events. Several parents described these latter two types (which often entailed the use of French words) as pewe ('lies'). Adults labeled tellings with any type of mixing as inauthentic (kilaama).

In Maroua, a linguistically and culturally heterogeneous urban setting, many Fulbe are concerned that their children are not learning to speak Fulfulde laamnde ('pure, clear Fulfulde') and that they are ignorant of many Fulbe traditions, including folktales. These concerns are not unfounded. Fulfulde is the lingua franca in northern Cameroon. As such, it is undergoing significant simplification of its phonology, morphology, syntax, lexicon, and pragmatics (Fagerli 1997, Métangmo-Tatou 1999, Noss 1979). The Diamare dialect spoken by Maroua Fulbe is conservative in comparison to the dialects spoken further south. Many younger Fulbe in Maroua, however, do not speak this Fulfulde laamnde but rather Fulfulde delemre ('Fulfulde light'). Participants attributed this to exposure to the Fulfulde spoken by non-natives (Bilkiire) and to French through government schooling and mass media. As the two transcripts show, Guided Repetition folktale socialization provided opportunities for adults to negatively assess and correct children's less than "pure" Fulfulde. Such opportunities were not always taken, however, nor did corrections appear to have a lasting effect on children's language use.

As for the oral traditions, it is not clear if they are in decline. Many of the young Fulbe in my study, carried out in 1999 and 2000-2001, knew several folktales and identified one or more expert tellers from whom they learned. When asked if folktales were told in their household, however, many adults said that folktales were told only in villages. Older womenfolk expressed concern and regret that children were not learning folktales. Most children, adults explained, were more interested in television and soccer, or they were too busy with or too tired from their Koranic and/or public school studies.

Fulbe participation in both types of schooling has increased significantly in recent years. Over the past four decades, Koranic schools have expanded rapidly as the education of girls has become more widely accepted and children of both genders pursue their studies further (Santerre 1973, Seignobos \& Nassourou 2000). Fulbe participation in government schooling began to rise in the mid- 
1980s (when the Fulbe president of Cameroon left office and was replaced by a Christian from the south) and an increasing number of Fulbe children participate in both types of schooling (Iyébi-Mandjek 2000, Tourneux \& Iyébi-Mandjek 1994). Consequently, they have less time for recreation. Thursday evenings, when children did not attend Koranic school, were for many families the only occasions for hiirde. Even then, television often won out over folktales.

Judging by participants' retrospective self-reports and the absence of any mention in the extensive work on Fulbe folktales in Cameroon by Baumgardt (1988, 1994), Baumgardt \& Addi (2000), Eguchi ( 1974, 1978, 1980, 1982, 1984, 1993, 1994), and Noye (1971, 1976, 1982), Guided Repetition has seeped into the folktale socialization over the last 10 to 15 years. Why now? There are two likely factors: perceived peril to the oral tradition, and shifting expectations regarding the role of younger children in language centered activities.

Guided Repetition is well suited to teaching a fixed body of knowledge (cf., Wagner 1983). Moreover, it is a practice with which nearly all Maroua Fulbe are well acquainted through Koranic schooling. Aware that children today are not immersed in folktales as in the past, Fulbe women may be using a familiar and highly effective socialization practice from one genre (Koranic recitation) to teach another genre they perceive as being neglected and distorted.

The emergence of this new model of folktale socialization is contemporaneous with increased Fulbe participation in Koranic and public schooling, and Guided Repetition dominates in both institutions. Its use in the home setting may reflect changing beliefs among adults and children about how children best learn oral texts and the point at which they may appropriately assume the role of teller. In Guided Repetition interactions with adults and with their peers, young children actively claim tellership (Ochs \& Capps 2001) in an activity in which formerly they played a more passive role as recipient until puberty. This precocious tellership is highly scaffolded by more expert tellers, who encourage children to co-tell folktales before they have learned them by observing multiple expert performances.

Increasingly, children learn folktales from other children, and they often use Guided Repetition amongst themselves, as Transcript 5 shows. Here, Hajja teaches her cousins Faariku and Adiilu a story she calls a folktale (taalol). This excerpt of Hajja's tale contains some features that are typical of those told by younger children. She mixes in elements of modernity (mota in lines 5, 6, and 7) and she does not follow conservative norms of noun class marking, referring to Older Sister with the neutral pronoun $d u m$ rather than the third person singular pronoun mo (line 6). 
Transcript 5: Peer Modeling-Imitation of a Folktale

Hajja: O metti non, He got angry like that

F \& A: O metti non, He got angry like that

H: $\quad$ O wi' ush ush ush

He said ush ush ush

F \& A: $\quad$ O wi' ush ush ush

He said ush ush ush

$\mathrm{H}: \quad$ Adda kam mota-

As for Older Sister the car

Adda kam mota yaa6i dum.

Older Sister the car ran over her.

F \& A: Adda kam mota yaa i um.

Older Sister the car ran over her.

H: $\quad$ Sui,

Finished

F \& A: $\quad$ Sui,

Finished

H: Kadi.

Then.

F \& A: Kadi.

Then.

Child-child folktale socialization often took place during daylight hours, a violation of the traditional restriction that folktales be told only at night. Several older children told me that they had taught and learned folktales at Koranic school when the mallum was not present. Such sites of clandestine peer socialization may be where the diffusion of Guided Repetition into the folktale domain began; they are certainly sites where the transfer is reinforced. 
Contrary to Noye's dire prediction, the Fulbe of Maroua continue to teach and tell folktales to their children. Increased participation in schooling may pose a threat to oral traditions by filling children's days and minds. Yet school patterns of language socialization have been adopted and adapted by children and adults for the learning and teaching of folktales. By expanding their repertoire of language socialization practices and applying practices from one domain to another, one genre to another, Maroua Fulbe have transformed and sustained the folktale tradition.

\section{REFERENCES}

Baumgardt, Ursula. 1988. "L'enfant à travers les contes peuls du Cameroun." In L'enfant dans les contes africains, ed. by Ursula Baumgardt and Veronika Görög-Karady, pp. 83-114. Paris: Conseil International de la Langue Française.

- 1994. "La représentation de l'autre: L'exemple du répertoire d'une conteuse peule de Garoua (Cameroun)." Cahiers d'Études Africaines 133135:295-311.

Baumgardt, Ursula, and Goggo Addi. 2000. Une conteuse peule et son répertoire:

Goggo Addi de Garoua, Cameroun: Textes et analyses. Paris: Karthala.

Eguchi, Paul K. 1974. Miscellany of Maroua Fulfulde (Northern Cameroun): African Languages and Ethnography. Tokyo: Institute for the Study of Languages and Cultures of Asia and Africa (ILCAA), Tokyo University of Foreign Studies.

. 1978-1980-1982-1984. Fulfulde Tales of North Cameroon. 4 vols. African Languages and Ethnography. Tokyo: ILCAA.

. 1993. "'Fulbe-ness' in Fulbe oral literature of Cameroon." Senri Ethnological Studies 35:181-200.

. 1994. "Pastoralism in Fulbe folktales." Cahiers d'Études Africaines 133135:7-22.

Fagerli, Ole Torfinn. 1997. "Language contact - structure changes: The Aadaamaawa Fulfulde case." Paper presented at the 2nd World Congress of African Linguistics. Leipzig, Germany.

Iyébi-Mandjek, Olivier. 2000. "Enseignement." In Atlas de la province ExtrêmeNord, Cameroun, ed. by Christian Seignobos and Olivier Iyébi-Mandjek. Paris: Éditions de l'Institut de Recherche pour le Développement, Institut National de Cartographie, République du Cameroun. 
Métangmo-Tatou, L. 1999. "Acquisition du langage chez l'enfant et processus de pidginisation: Le cas du bilkiire ou 'parler enfantin' au nord du Cameroun." Paper presented at the Colloque Méga-Tchad: Les enfants dans le bassin du Lac Tchad, 9-11 June 1999. Leiden.

Moore, Leslie C. 2004. Learning Languages by Heart: Language Socialization in a Fulbe Community (Maroua, Cameroon). Ph.D. dissertation, UCLA.

Noss, Philip A. 1979. "Fula: A language of change." In Readings in Creole Studies, ed. by Ian F. Hancock, pp. 173-88. Ghent: Story-Scientia.

Noye, Dominique. 1971. Un cas d'apprentissage linguistique: L'acquisition de la langue par les jeunes Peuls du Diamare (Nord-Cameroun). Thèse doctorat de Troisième Cycle.

. 1976. Blasons peuls: Eloges et satires du Nord Cameroun. Paris: Geuthner.

. 1982. "Pédagogie traditionnelle d'une langue africaine." In La quête du savoir: Essais pour une anthropologie de l'éducation camerounaise, ed. by Renaud Santerre and Céline Mercier-Tremblay, pp. 312-25. Montreal: Presses de l'Université de Montréal.

Ochs, Elinor, and Lisa Capps. 2001. Living Narrative: Creating Lives in Everyday Storytelling. Cambridge, MA: Harvard University Press.

Santerre, Renaud. 1973. Pédagogie musulmane d'Afrique noire: L'école coranique peule du Cameroun. Montreal: Presses de l'Université de Montréal. Seignobos, Christian, and Abdourhaman Nassourou. 2000. "Réligions." In Atlas de la province Extrême-Nord, Cameroun, ed. by Christian Seignobos and Olivier Iyébi-Mandjek. Paris: Éditions de l'Institut de Recherche pour le Développement / Ministère de la Recherche Scientifique et Technique, Institut National de Cartographie, République du Cameroun.

Tourneux, Henry, and Olivier Iyébi-Mandjek. 1994. L'école dans une petite ville africaine (Maroua, Cameroun). Paris: Karthala.

Wagner, Daniel A. 1983. "Rediscovering 'rote': Some cognitive and pedagogical preliminaries." In Human Assessment and Cultural Factors, ed. by John W. Berry and S. H. Irvine, pp. 179-90. New York: Plenum.

Leslie C. Moore

University of California, Santa Cruz email: lesmoore@ucsc.edu 